Wicaksono, F.Y. • A. Ratnasari $\cdot$ R.H. Shabira $\cdot$ R.E. Sutrisna $\cdot$ Ruminta

\title{
Respons varietas-varietas gandum terhadap pemupukan silika organik di dataran medium
}

Sari Penanaman gandum dari dataran medium sampai ke rendah memiliki kendala, salah satunya yaitu cekaman suhu tinggi. Pemupukan silika merupakan usaha yang dapat dilakukan agar tanaman gandum tahan terhadap cekaman suhu tinggi. Penelitian ini bertujuan untuk mengetahui pengaruh interaksi antara dosis pupuk silika yang terbuat dari abu ketel pabrik gula dan varietas gandum terhadap pertumbuhan dan hasil gandum pada dataran medium yang lebih panas dibandingkan dengan dataran tinggi. Penelitian ini dilaksanakan pada bulan Januari 2018 - April 2018 di kebun percobaan Ciparanje Fakultas Pertanian Universitas Padjadjaran, Jatinangor, pada ketinggian $750 \mathrm{~m}$ di atas permukaan laut. Rancangan percobaan yang digunakan adalah Rancangan Petak Terbagi dengan petak utama adalah varietas dan anak petak adalah dosis pupuk silika. Faktor varietas terdiri dari 3 taraf, yaitu varietas Dewata, Selayar, dan GURI-6; sementara faktor dosis pupuk silika terdiri dari 6 taraf, yaitu 50, 100, 150, 200, 250, dan $300 \mathrm{~kg} / \mathrm{ha}$. Semua perlakuan diulang sebanyak 2 kali. Pengamatan dilakukan pada komponen pertumbuhan dan hasil tanaman gandum. Hasil penelitian menunjukkan terdapat pengaruh interaksi antara varietas dan dosis pupuk silika terhadap persentase biji bernas dan kadar gluten. Pengaruh mandiri dosis pupuk silika taraf $100 \mathrm{~kg} / \mathrm{ha}$ memberikan Indeks Luas Daun dan Indeks Panen lebih tinggi dengan nilai masing-masing 3,44 dan 0,38. Pengaruh mandiri varietas GURI-6 memberikan hasil paling baik pada karakter tinggi tanaman dan panjang malai, sebesar $70,44 \mathrm{~cm}$ dan $6,26 \mathrm{~cm}$.

Kata kunci : Silika · Cekaman· Gandum

\section{Response of wheat varieties due to organic silica fertilization in medium land}

\begin{abstract}
Wheat cultivation in medium or lowland can suffer heat stress. Silica fertilization is an effort to decrease heat stress on wheat crop. This study aims to find the interaction between silica fertilizer doses made from sugar mill ash and wheat varieties on growth and yield of wheat. The experiment was conducted on January 2018 until April 2018 in Ciparanje experimental field, Faculty of Agriculture, Padjadjaran University, Sumedang, at an altitude of $750 \mathrm{~m}$ above sea level. The Experiment used Split Plot Design which used wheat varieties as main plot and silica fertilizer doses as subplot. Main plot consisted of 3 levels of variety, there were Dewata, Selayar, and GURI-6; while subplot consisted of 6 levels of silica fertilizer dose, there were 50,100, 150, 200, 250, and $300 \mathrm{~kg} / \mathrm{ha}$. All treatments were replicated twice. Observations were made on the components of growth and yield of wheat crop. The results showed interaction effect between varieties and silica fertilizer dosages on the percentage of filling grain and gluten content. The single effect of silica fertilizer level of $100 \mathrm{~kg} / \mathrm{ha}$ gave a higher Leaf Area Index and Harvest Index values, were 3.44 and 0.38 . GURI-6 variety gave the best results on plant height and panicle length, were $70,44 \mathrm{~cm}$ and $6,26 \mathrm{~cm}$.
\end{abstract}

Keywords : Silica $\cdot$ Stress $\cdot$ Wheat

Diterima : 29 Maret 2020, Disetujui : 21 Juli 2020, Dipublikasikan : 12 Agustus 2020 doi: https://doi.org/10.24198/kultivasi.v19i2.26746

Wicaksono, F.Y. · A. Ratnasari · R.H. Shabira · R.E. Sutrisna · Ruminta

Prodi Agroteknologi, Fakultas Pertanian, Universitas Padjadjaran

Korespondensi: fiky.yulianto@unpad.ac.id 


\section{Pendahuluan}

Gandum (Triticum aestivum L.) merupakan komoditas penting di berbagai negara, yang banyak dimanfaatkan sebagai bahan pangan dan bahan baku industri. Gandum memiliki nilai lebih karena kandungan gluten yang dimilikinya sehingga dapat dijadikan berbagai pangan olahan. Dari segi agronomis, tanaman gandum menghendaki suhu yang rendah yaitu berkisar $15^{0}-25^{\circ} \mathrm{C}$ untuk pertumbuhan yang optimal. Kendala pada penanaman gandum di dataran rendah adalah suhu yang tinggi (Wahyu et al., 2013). Suhu tinggi akan mengakibatkan cekaman panas yang terlihat pada penurunan laju pertumbuhan dan bobot bulir pada hasil tanaman serealia (Saradadevi et al., 2014). Penanaman gandum di dataran medium maupun rendah dapat menurunkan produktivitas tanaman gandum di Indonesia (Ariani et al., 2015)

Pemupukan silika (Si) dapat menjadi salah satu usaha untuk meningkatkan produktivitas gandum yang mengalami stress suhu tinggi. Silika mempunyai peran pentingpada tanaman graminae seperti padi, jagung juga gandum karena familia Graminae merupakan tanaman akumulator Si yang terdapat pada permukaan daun, batang dan gabah. Peran penting Si diantaranya meningkatkan hasil tanaman dan meningkatkan daya tahan terhadap serangan hama dan penyakit; meningkatkan efisiensi dan translokasi hasil fotosintesis; memperkuat akar tanaman dan meningkatkan root oxidizing power untuk mengurangi keracunan $\mathrm{Fe}$, $\mathrm{Al}$ dan $\mathrm{Mn}$; serta menekan laju transpirasi sehingga efisien dalam penggunaan air dan lebih tahan cekaman kekeringan (Ma, 2003). Pupuk Si diketahui dapat meningkatkan pertumbuhan dan hasil gandum varietas Dewata bila dibandingkan dengan tanpa aplikasi pupuk Si (Wicaksono et al., 2016).

Efek dari $\mathrm{Si}$ pada pertumbuhan kebanyakan tanaman menjadi lebih terasa saat berada di kondisi stres seperti kekeringan dan panas (Makarim et al., 2007). Membran sel merupakan target kritis utama dari stres abiotik (Taiz dan Zeiger, 2002). Banyak gejala fisiologis yang terjadi karena kerusakan dari membran sel. Tanaman yang diberi perlakuan Si memiliki toleransi pada keadaan cekaman panas dan kekeringan hal ini disebabkan $\mathrm{Si}$ memiliki peranan yang signifikan dalam perawatan kekuatan dari membran sel (Agarie et al., 2015). Stabilitas membran sel, kandungan air relatif, dan aktivitas antioksidan merupakan komponen pada tanaman yang terganggu akibat cekaman panas. Silikat diketahui dapat meningkatkan stabilitas membran kloroplas, disebabkan oleh kadar air relatif sel dan stabilitas membran yang dijaga sehingga kandungan klorofil dalam daun tidak berkurang ketika terjadi cekaman panas (Sujatha et al., 2013; Wicaksono et al., 2016)

Usaha lain selain pemupukan $\mathrm{Si}$ adalah dengan menggunakan varietas unggul yang telah ditingkatkan potensi genetiknya (Nurmala et al., 2015). Varietas unggul gandum yang ada di Indonesia antara lain varietas Dewata, Selayar, dan GURI. Varietas-varietas ini memiliki keunggulannya masing-masing. Varietas-varietas tersebut masih harus diteliti mana yang responsif terhadap berbagai dosis pupuk $\mathrm{Si}$ agar tahan terhadap cekaman kekeringan dan panas. Hal ini sejalan dengan program pemerintah untuk menghasilkan gandum yang adaptif di dataran menengahrendah maka percobaan pemupukan Si dan beberapa varietas ini diharapkan dapat mengembangkan penanaman gandum yang adaptif terhadap cekaman kekeringan dan panas.

\section{Bahan dan Metode}

Penelitian ini dilakukan dari Januari 2018 April 2018 di Kebun Percobaan Ciparanje Fakultas Pertanian Universitas Padjadjaran, Jatinangor, Kabupaten Sumedang Jawa Barat. Ketinggian tempat lokasi penelitian sekitar 780 $\mathrm{m}$ di atas permukaan laut, dengan tipe iklim C3 menurut klasifikasi Oldeman dan ordo tanah Inceptisol.

Peralatan yang digunakan mulai dari persiapan lahan hingga panen adalah cangkul, kored, sabit, ember, tali, patok, papan nama, selang, dan peralatan penunjang lainnya. Peralatan untuk pengamatan berupa berupa mistar, meteran, klorofil meter SPAD, timbangan analitik, grinder, alat tulis dan alat dokumentasi. Percobaan menggunakan rancangan percobaan petak terpisah (Split plot design) dengan menggunakan varietas gandum yang dilepas oleh Badan Litbang Pertanian yang diperoleh dari Balai Penelitian Tanaman Serealia di Maros, Sulawesi Selatan, sebagai petak utama 
sedangkan dosis pupuk silika sebanyak 6 taraf sebagai sub plot. Faktor varietas (V) terdiri dari tiga taraf, yaitu varietas Dewata ( $\left.\mathrm{v}_{1}\right)$, Selayar $\left(\mathrm{v}_{2}\right)$, dan GURI-6 ( $\left.\mathrm{v}_{3}\right)$, sementara faktor dosis pupuk Si (S) terdiri dari 6 taraf, yaitu $50 \mathrm{~kg} / \mathrm{ha}$ $\left(\mathrm{s}_{1}\right), 100 \mathrm{~kg} / \mathrm{ha}\left(\mathrm{s}_{2}\right), 150 \mathrm{~kg} / \mathrm{ha}\left(\mathrm{s}_{3}\right), 200 \mathrm{~kg} / \mathrm{ha}$ $\left(\mathrm{s}_{4}\right), 250 \mathrm{~kg} / \mathrm{ha}\left(\mathrm{s}_{5}\right)$, dan $300 \mathrm{~kg} / \mathrm{ha}\left(\mathrm{s}_{6}\right)$.

Setiap perlakuan diulang sebanyak 2 kali, sehingga terdapat 36 petak percobaan. Percobaan dilakukan pada lahan seluas $240 \mathrm{~m}^{2}$ dengan ukuran petak perlakuan percobaan $2 \times 2$ $\mathrm{m}^{2}$. Pemupukan yang dilakukan adalah pupuk dasar menggunakan pupuk kendang kotoran ayam 20 ton/ha, pupuk urea $200 \mathrm{~kg} /$ ha, pupuk SP $36200 \mathrm{~kg} / \mathrm{ha}$ dan pupuk $\mathrm{KCl} 100 \mathrm{~kg} / \mathrm{ha}$. Pemberian pupuk perlakuan Si dari abu ketel sesuai dosis perlakuan dengan kandungan $\mathrm{SiO}_{2}$ sebesar 34,35\% yang diperoleh dari PT. Rajawali Nusantara Indonesia, Subang.

Pengamatan yang diamati adalah komponen pertumbuhan (tinggi tanaman, Indeks Luas Daun (ILD), jumlah anakan, dan kandungan klorofil) dan komponen hasil (panjang malai, jumlah malai, bobot 100 butir, dan indeks panen). Indeks luas daun dihitung dengan membandingkan total luas daun dengan luas kanopi. Luas daun dihitung menggunakan persamaan regresi yang dicari terlebih dahulu dari 30 sampel yang mencari hubungan antara luas daun (A) dengan panjang (p) kali lebar daun (l). Persamaan regresi yang diperoleh adalah $\mathrm{A}=0,5 \times \mathrm{p} \times 1$. Indeks panen dihitung dengan bobot bernilai ekonomi (biji gandum) dengan bobot tanaman total. Pengamatan penunjang yang diamati adalah analisis Si tanah awal dan akhir, data cuaca, serta umur berbunga dan umur panen.

Data dianalisis secara statistik dengan uji $\mathrm{F}$ pada taraf nyata $5 \%$ untuk mengetahui minimal ada sepasang perlakuan yang berbeda nyata. Uji lanjut untuk mengetahui perlakuan mana yang memberikan pengaruh tidak nyata menggunakan Uji Jarak Berganda Duncan pada taraf nyata $5 \%$. Semua analisis menggunakan program SPSS®.

\section{Hasil dan Pembahasan}

Kandungan awal Si tanah dalam tanah percobaan ini adalah sebesar 27,80 \% termasuk kedalam kriteria tinggi berada di dalam tanah. Kandungan akhir Si tanah setelah dilakukan analisis menjadi $28,96 \%$. Kenaikan ini diduga karena ada penambahan dari pupuk Si yang diberikan dan dikurangi penyerapan oleh tanaman.

Rata-rata suhu saat masa pertumbuhan pada bulan Desember 2017 - Februari 2018 adalah 23,1 ${ }^{\circ} \mathrm{C}$ dengan suhu maksimum $31^{\circ} \mathrm{C}$ diukur pada pukul 13.00. Suhu pada fase pembungaan di bulan Februari - Maret adalah $22,9 \circ \mathrm{C}$ dengan suhu maksimum $27,2{ }^{\circ} \mathrm{C}$ dan suhu minimum $20,5{ }^{\circ} \mathrm{C}$. Suhu pada pengisian malai hingga panen memiliki rata-rata $23{ }^{\circ} \mathrm{C}$ dengan suhu maksimum $30{ }^{\circ} \mathrm{C}$ dan suhu minimum $17,8{ }^{\circ} \mathrm{C}$. Gandum menghendaki suhu dengan kisaran $15{ }^{\circ} \mathrm{C}-25{ }^{\circ} \mathrm{C}$ (Wahyu et al., 2013). Pada suhu tinggi laju perkembangan tanaman akan meningkat sehingga menurunkan potensi akumulasi biomassa. Secara umum suhu tinggi dapat menurunkan hasil seperti jumlah butir dan berat biji per malai (Ferris et al., 1999).

Menurut deskripsi masing-masing umur berbunga setiap varietas sebagai berikut: Varietas Dewata berbunga pada umur 55 hari setelah tanam (HST), Varietas Selayar 80 HST, dan GURI-6 66 HST. Umur berbunga pada percobaan ini dibandingkan dengan deskripsi terlihat bahwa varietas Dewata berbunga lebih cepat 1 hari yaitu pada 54 HST, varietas Selayar berbunga lebih cepat 25 hari yaitu pada 55 HST, dan varietas GURI-6 berbunga lebih cepat 11 hari yaitu pada 55 HST. Hal ini sesuai dengan pernyataan Aqil et al., (2011), bahwa tanaman gandum di dataran rendah tropis dapat berbunga lebih cepat (35-51 hari) dibandingkan dengan gandum di dataran tinggi.

Hasil uji statistik menunjukkan terdapatnya pengaruh interaksi antara varietas dan dosis pupuk $\mathrm{Si}$ terhadap komponen persentase biji isi dan kadar gluten. Pengaruh mandiri varietas serta pengaruh mandiri dosis pupuk Si memberikan perbedaan yang nyata pada beberapa parameter pengamatan.

Komponen Pertumbuhan. Pengaruh mandiri varietas berpengaruh nyata pada tinggi tanaman dan indeks kandungan klorofil, sementara pengaruh mandiri dosis pupuk $\mathrm{Si}$ berpengaruh terhadap ILD (Tabel 1). Budiarti (2005) membagi gandum kedalam beberapa kelompok dalam karakter tinggi tanaman. Kategori pendek untuk tanaman dengan kisaran $53,5-65,2 \mathrm{~cm}$, sedang $65,2-76,9 \mathrm{~cm}$, dan tinggi $>76,9 \mathrm{~cm}$. Hasil percobaan menunjukan bahwa faktor genetik pada varietas mempengaruhi tinggi tanaman gandum. Varietas Selayar 
termasuk kategori pendek, sedangkan Dewata dan GURI - 6 termasuk kategori sedang. Ketinggian tanaman dan panjang malai pada daerah tropis dipengaruhi oleh ketinggian tempat, sehingga semakin tinggi tempat maka akan meningkat pula tinggi tanaman dan panjang malai (Samosir, 2011). Hal ini yang menyebabkan tidak adanya pengaruh dari pupuk Si terhadap tinggi tanaman. Kemungkinan lain adalah kandungan Si tanah yang sudah tinggi sehingga pemberian pupuk Si tidak mempengaruhi pada tinggi tanaman. Si juga tidak memberikan perbedaan nyata terhadap tinggi, namun mungkin memiliki pengaruh dalam membuat tanaman memiliki batang dan daun yang tegak sehingga tidak mudah rebah. Hal ini sesuai dengan pernyataan Song et al. (2011), bahwa Si meningkatkan kekuatan jaringan pada batang, daun dan akar, Si juga meningkatkan kekuatan mekanik dinding sel. Oleh karena itu, perlu penelitian lebih lanjut untuk melihat ketegaran batang setelah aplikasi Si.

Varietas juga kemungkinan memberikan indeks kandungan klorofil yang berbeda karena faktor genetik sehingga pengaruh varietas menjadi berbeda. Hal ini sesuai dengan penelitian Guendoz dan Maamari (2012) bahwa klorofil gandum pada berbagai varietas dapat berbeda. Pupuk Si tidak memberikan perbedaan yang nyata terhadap indeks kandungan klorofil dan jumlah anakan tanaman. Hal ini kemungkinan disebabkan kandungan Si yang sudah tinggi di tanah sehingga ketersediannya menjadi besar yang mengakibatkan pemberian pupuk Si tidak berpengaruh nyata. Hasil yang berbeda diperoleh oleh penelitian Wicaksono et al. (2016), bahwa pupuk Si dapat meningkatkan jumlah anakan gandum varietas Dewata pada kandungan Si tanah yang juga tinggi. Hal ini dapat disebabkan ketersediaan $\mathrm{Si}$ di tanah rendah meskipun kandungan Si tanah tinggi. Pengaruh mandiri varietas terhadap jumlah anakan juga tidak berbeda nyata. Hal ini sesuai dengan penelitian Wirawan et al. (2013), bahwa jumlah anakan varietas Selayar, Dewata, dan beberapa galur lain tidak berbeda.

Pengaruh mandiri varietas tidak memberikan perbedaan yang nyata terhadap ILD, namun pengaruh mandiri dosis $\mathrm{Si}$ memberikan perbedaan yang nyata terhadap ILD (Tabel 1). Silika diketahui cenderung dapat meningkatkan luas daun (Sari et al., 2017). Dosis pemupukan Si yang terbaik adalah $100 \mathrm{~kg} / \mathrm{ha}$, namun dosis ini masih di bawah dosis rekomendasi untuk pemupukan Si pada varietas Dewata, yaitu $250 \mathrm{~kg} / \mathrm{ha}$ (Wicaksono et al., 2016). Hal ini kemungkinan karena kandungan dan ketersediaan Si pada tanah telah tinggi, sehingga kebutuhan Si untuk tanaman gandum telah tersedia di tanah.

Tabel 1. Pengaruh mandiri varietas dan pengaruh mandiri dosis Si terhadap komponen pertumbuhan gandum.

\begin{tabular}{|c|c|c|c|c|c|c|c|c|}
\hline \multirow{2}{*}{$\begin{array}{l}\text { Perlakuan } \\
\text { Varietas }\end{array}$} & \multicolumn{2}{|c|}{$\begin{array}{c}\text { Tinggi } \\
\text { tanaman } 8 \\
\text { MST }(\mathrm{cm})\end{array}$} & \multicolumn{2}{|c|}{$\begin{array}{c}\text { Indeks } \\
\text { Kandungan } \\
\text { Klorofil } 8 \text { MST }\end{array}$} & \multicolumn{2}{|c|}{$\begin{array}{l}\text { Jumlah anakan } \\
8 \mathrm{MST}\end{array}$} & \multicolumn{2}{|c|}{ ILD 8 MST } \\
\hline & & & & & & & & \\
\hline $\mathrm{v}_{1}$ (Dewata) & 65,70 & $a b$ & 26,60 & $\mathrm{a}$ & 4,58 & a & 2,87 & a \\
\hline v2 (Selayar) & 54,85 & a & 37,17 & $\mathrm{c}$ & 4,31 & $\mathrm{a}$ & 2,57 & $\mathrm{a}$ \\
\hline $\mathrm{v}_{3}(\mathrm{GURI}-6)$ & 70,44 & $\mathrm{~b}$ & 31,13 & $\mathrm{~b}$ & 4,88 & a & 2,65 & a \\
\hline \multicolumn{9}{|l|}{ Dosis Pupuk Si } \\
\hline $\mathrm{s}_{1}(50 \mathrm{~kg} / \mathrm{ha})$ & 75,62 & $\mathrm{a}$ & 38,66 & $\mathrm{a}$ & 5,41 & a & 3,00 & a \\
\hline $\mathrm{s}_{2}(100 \mathrm{~kg} / \mathrm{ha})$ & 76,44 & $\mathrm{a}$ & 38,07 & $\mathrm{a}$ & 5,56 & a & 3,44 & c \\
\hline $\mathrm{s}_{3}(150 \mathrm{~kg} / \mathrm{ha})$ & 76,78 & $\mathrm{a}$ & 37,95 & $\mathrm{a}$ & 5,40 & $\mathrm{a}$ & 3,11 & $a b$ \\
\hline $\mathrm{s}_{4}(200 \mathrm{~kg} / \mathrm{ha})$ & 77,10 & $\mathrm{a}$ & 37,46 & $\mathrm{a}$ & 5,65 & a & 3,43 & $b c$ \\
\hline $\mathrm{s}_{5}(250 \mathrm{~kg} / \mathrm{ha})$ & 76,03 & $\mathrm{a}$ & 37,65 & $\mathrm{a}$ & 5,53 & a & 3,32 & $b c$ \\
\hline $\mathrm{s}_{6}(300 \mathrm{~kg} / \mathrm{ha})$ & 77,85 & $\mathrm{a}$ & 37,13 & $\mathrm{a}$ & 5,40 & $\mathrm{a}$ & 3,20 & $a b c$ \\
\hline
\end{tabular}

Keterangan: nilai rata-rata yang diikuti oleh huruf yang sama menunjukkan tidak berbeda nyata berdasarkan uji jarak berganda Duncan pada taraf nyata 5\%. MST: minggu setelah tanam 
Tabel 2. Pengaruh interaksi antara varietas dan dosis Si terhadap persentase biji isi gandum (\%).

\begin{tabular}{|c|c|c|c|c|c|c|c|c|c|c|c|c|}
\hline \multirow{2}{*}{ Varietas } & \multicolumn{12}{|c|}{ Dosis pupuk Si } \\
\hline & \multicolumn{2}{|l|}{$\mathrm{s}_{1}$} & \multicolumn{2}{|c|}{$\mathrm{S}_{2}$} & \multicolumn{2}{|c|}{$\mathrm{S}_{3}$} & \multicolumn{2}{|c|}{$\mathrm{S}_{4}$} & \multicolumn{2}{|c|}{$\mathrm{S}_{5}$} & \multicolumn{2}{|l|}{$\mathrm{s}_{6}$} \\
\hline \multirow[b]{2}{*}{$\mathrm{V}_{1}$} & 42,7 & $\mathrm{~b}$ & 35,34 & $\mathrm{a}$ & 26,6 & $\mathrm{a}$ & 26,5 & $\mathrm{a}$ & 43,1 & $a b$ & 35,9 & $\mathrm{~b}$ \\
\hline & $\mathrm{A}$ & & A & & A & & $\mathrm{A}$ & & A & & A & \\
\hline \multirow[b]{2}{*}{$\mathrm{V}_{2}$} & 40,2 & $b$ & 39,34 & $\mathrm{ab}$ & 40,8 & $b$ & 33,2 & $\mathrm{a}$ & 33,5 & $\mathrm{a}$ & 29,7 & $a b$ \\
\hline & A & & A & & A & & A & & A & & A & \\
\hline \multirow[b]{2}{*}{$\mathrm{V}_{3}$} & 14,7 & $\mathrm{a}$ & 44,5 & $\mathrm{~b}$ & 45,4 & $b$ & 46,6 & $\mathrm{~b}$ & 48,5 & $\mathrm{~b}$ & 19,8 & $\mathrm{a}$ \\
\hline & A & & B & & B & & B & & B & & $\mathrm{A}$ & \\
\hline
\end{tabular}

Keterangan: nilai rata-rata yang diikuti oleh huruf kapital (arah horizontal) atau huruf kecil (arah vertikal) yang sama menunjukkan tidak berbeda nyata berdasarkan uji jarak berganda Duncan pada taraf nyata $5 \%$.

Tabel 3. Pengaruh mandiri varietas dan pengaruh mandiri dosis Si terhadap komponen hasil gandum.

\begin{tabular}{|c|c|c|c|c|c|c|c|c|}
\hline \multirow{2}{*}{$\begin{array}{l}\text { Perlakuan } \\
\text { Varietas }\end{array}$} & \multicolumn{2}{|c|}{$\begin{array}{c}\text { Jumlah malai } \\
\text { per } \mathrm{m}^{2}\end{array}$} & \multicolumn{2}{|c|}{$\begin{array}{c}\text { Panjang malai } \\
(\mathrm{cm})\end{array}$} & \multicolumn{2}{|c|}{$\begin{array}{c}\text { Bobot } 100 \text { butir } \\
(\mathrm{g})\end{array}$} & \multicolumn{2}{|c|}{ Indeks Panen } \\
\hline & & & & & & & & \\
\hline $\mathrm{v}_{1}$ (Dewata) & 60,08 & $\mathrm{~b}$ & 6,10 & $b$ & 2,08 & $\mathrm{a}$ & 0,29 & $\mathrm{a}$ \\
\hline $\mathrm{v}_{2}$ (Selayar) & 43,50 & $\mathrm{a}$ & 5,82 & $\mathrm{a}$ & 2,56 & $\mathrm{~b}$ & 0,28 & $\mathrm{a}$ \\
\hline $\mathrm{v}_{3}(\mathrm{GURI}-6)$ & 59,08 & $\mathrm{~b}$ & 6,26 & c & 2,40 & $\mathrm{~b}$ & 0,28 & $\mathrm{a}$ \\
\hline \multicolumn{9}{|l|}{ Dosis Pupuk Si } \\
\hline $\mathrm{s}_{1}(50 \mathrm{~kg} / \mathrm{ha})$ & 67,00 & $\mathrm{a}$ & 7,32 & $\mathrm{a}$ & 2,77 & $\mathrm{a}$ & 0,33 & $\mathrm{a}$ \\
\hline $\mathrm{s}_{2}(100 \mathrm{~kg} / \mathrm{ha})$ & 69,17 & $\mathrm{a}$ & 7,25 & $\mathrm{a}$ & 2,76 & $\mathrm{a}$ & 0,38 & $\mathrm{~b}$ \\
\hline $\mathrm{s}_{3}(150 \mathrm{~kg} / \mathrm{ha})$ & 62,50 & $\mathrm{a}$ & 7,37 & $\mathrm{a}$ & 2,79 & $\mathrm{a}$ & 0,32 & $\mathrm{a}$ \\
\hline $\mathrm{s}_{4}(200 \mathrm{~kg} / \mathrm{ha})$ & 59,50 & $\mathrm{a}$ & 7,30 & $\mathrm{a}$ & 2,92 & $\mathrm{a}$ & 0,33 & $\mathrm{a}$ \\
\hline $\mathrm{s}_{5}(250 \mathrm{~kg} / \mathrm{ha})$ & 67,17 & $\mathrm{a}$ & 7,17 & a & 2,83 & $\mathrm{a}$ & 0,34 & $\mathrm{a}$ \\
\hline $\mathrm{s}_{6}(300 \mathrm{~kg} / \mathrm{ha})$ & 64,50 & $\mathrm{a}$ & 7,30 & $\mathrm{a}$ & 2,74 & $\mathrm{a}$ & 0,37 & $\mathrm{~b}$ \\
\hline
\end{tabular}

Keterangan: nilai rata-rata yang diikuti oleh huruf yang sama menunjukkan tidak berbeda nyata berdasarkan uji jarak berganda Duncan pada taraf nyata $5 \%$.

Pengaruh interaksi terjadi pada komponen persentase biji isi (Tabel 2). Pada varietas Dewata dan selayar, peningkatan dosis Si tidak memberikan perbedaan yang nyata, namun pada varietas Guri-6 peningkatan mulai dari 100 - $250 \mathrm{~kg} / \mathrm{ha}$ memberikan persentase biji isi yang lebih baik. Suhu tinggi akan menurunkan hasil seperti jumlah butir per malai (Ferris et al., 1999, Nur 2013). Jumlah butir berkurang karena berkurangnya persentase biji isi. Adanya aplikasi Si menyebabkan tanaman dapat meningkatkan hasil pada suhu yang lebih panas. Tanaman yang diberi perlakuan Si memiliki toleransi pada keadaan cekaman panas dan kekeringan hal ini dikarenakan Si memiliki peranan yang signifikan untuk memperkuat membran sel (Agarie et al., 2015).

Pengaruh mandiri varietas memberikan perbedaan yang nyata terhadap jumlah malai, panjang malai, serta bobot 100 butir, namun pengaruh mandiri dosis Si tidak memberikan perbedaan yang nyata pada ketiga parameter tersebut (Tabel 3). Perbedaan pada jumlah malai, panjang malai, serta bobot 100 butir oleh pengaruh varietas kemungkinan disebabkan oleh faktor genetik (Wicaksono et al., 2016). Tidak adanya perbedaan nyata pada jumlah malai, panjang malai, serta bobot 100 butir kemungkinan disebabkan oleh kandungan Si yang tinggi pada tanah. Pengaruh mandiri varietas malah tidak memberikan perbedaan yang nyata terhadap indeks panen, namun justru pengaruh mandiri dosis $\mathrm{Si}$ yang memberikan perbedaan yang nyata. Silika diketahui dapat meningkatkan hasil tanaman (Ma, 2003) sehingga indeks panen menjadi lebih besar. Dosis pemupukan Si yang memberikan perbedaan nyata dengan dosis Si yang lain adalah $100 \mathrm{~kg} / \mathrm{ha}$ dan $300 \mathrm{~kg} / \mathrm{ha}$, namun dosis $100 \mathrm{~kg} / \mathrm{ha}$ dapat dipilih sebagai yang terbaik bila mempertimbangkan efisiensi. Analogi pada ILD, dosis terbaik masih di bawah dosis rekomendasi karena kandungan $\mathrm{Si}$ pada tanah yang tinggi. 
Tabel 4. Pengaruh interaksi antara varietas dan dosis Si terhadap kadar gluten (\%).

\begin{tabular}{|c|c|c|c|c|c|c|c|c|c|c|c|c|}
\hline \multirow{2}{*}{ Varietas } & \multicolumn{12}{|c|}{ Dosis pupuk $\mathrm{Si}$} \\
\hline & \multicolumn{2}{|c|}{$\mathrm{s}_{1}$} & \multicolumn{2}{|c|}{$\mathrm{s}_{2}$} & \multicolumn{2}{|c|}{$\mathrm{s}_{3}$} & \multicolumn{2}{|c|}{$\mathrm{s}_{4}$} & \multicolumn{2}{|c|}{$\mathrm{S}_{5}$} & \multicolumn{2}{|c|}{$\mathrm{S}_{6}$} \\
\hline \multirow{2}{*}{$\mathrm{V}_{1}$} & 14,9 & $\mathrm{a}$ & 15,56 & $\mathrm{a}$ & 17,59 & a & 18,4 & $a b$ & 18,06 & $\mathrm{a}$ & 16,4 & $\mathrm{a}$ \\
\hline & A & & $\mathrm{AB}$ & & B & & B & & B & & B & \\
\hline \multirow{2}{*}{$\mathrm{v}_{2}$} & 12,7 & $\mathrm{a}$ & 12,89 & $\mathrm{a}$ & 18,6 & a & 13,4 & $\mathrm{a}$ & 13,57 & $\mathrm{a}$ & 18,45 & $\mathrm{a}$ \\
\hline & A & & $\mathrm{AB}$ & & B & & B & & B & & B & \\
\hline \multirow{2}{*}{$\mathrm{v}_{3}$} & 29,3 & $\mathrm{~b}$ & 27,93 & $\mathrm{~b}$ & 24,79 & $\mathrm{~b}$ & 21 & $\mathrm{~b}$ & 24,69 & $\mathrm{~b}$ & 20,63 & $\mathrm{a}$ \\
\hline & B & & $\mathrm{AB}$ & & A & & A & & A & & A & \\
\hline
\end{tabular}

Keterangan: nilai rata-rata yang diikuti oleh huruf kapital (arah horizontal) atau huruf kecil (arah vertikal) yang sama menunjukkan tidak berbeda nyata berdasarkan uji jarak berganda Duncan pada taraf nyata $5 \%$.

Pengaruh interaksi terjadi pada komponen kadar gluten (Tabel 4). Pada varietas Dewata dan selayar, peningkatan dosis Si mulai dari 150 $\mathrm{kg} / \mathrm{ha}$ memberikan kadar gluten yang lebih baik, namun pada varietas Guri-6 justru malah menurunkan kadar gluten. Penelitian Wicaksono et al. (2016) juga menyebutkan bahwa pemberian Si pada dosis 150 - $250 \mathrm{~kg} / \mathrm{ha}$ dapat meningkatkan kadar gluten. Silika memiliki peran dalam mengurangi cekaman panas dan kekeringan dengan meningkatkan dinding sel dan jaringan xylem (Vasanthi et al., 2014) sehingga membuat fotosintesis berjalan optimal. Protein terdapat dalam endosperma biji, fotosintesis yang optimal menyebabkan pembentukan protein menjadi optimal sehingga kadar gluten menjadi lebih meningkat (Wicaksono et al., 2016). Sebagai catatan pada penelitian ini, penurunan kadar gluten pada varietas Guri-6 akibat peningkatan dosis Si perlu dikaji kembali.

\section{Kesimpulan}

Hasil penelitian menunjukkan terdapat pengaruh interaksi antara varietas dan dosis pupuk silika terhadap persentase biji bernas dan kadar gluten. Pengaruh mandiri dosis pupuk silika taraf $100 \mathrm{~kg} / \mathrm{ha}$ memberikan ILD dan Indeks Panen lebih tinggi dengan nilai 3,44 dan 0,38. Varietas GURI-6 memberikan hasil paling baik pada karakter tinggi tanaman dan panjang malai.

\section{Daftar Pustaka}

Agarie, S., N. Hanaoka, O. Ueno, A. Miyazaki, F. Kubota, W. Agata, and P.B. Kaufman. 2015. Effects of silicon on tolerance to water deficit and heat stress in rice plants (Oryza sativa L.), monitored by electrolyte leakage. Plant Production Science 1(2): 96 - 103. https://doi.org/10.1626/pps.1.96

Aqil, M., B.P. Marcia, dan H. Muslimah. 2011. Inovasi gandum adaptif dataran rendah. Majalah Sinar Tani Edisi (3390):12-13.

Ariani, E., F.Y. Wicaksono, A.W. Irwan, T. Nurmala, Y. Yuwariah. 2015. Pengaruh berbagai pengaturan jarak tanam dan konsentrasi giberelin (GA3) terhadap pertumbuhan dan hasil tanaman gandum (Triticum aestivum L.) kultivar dewata di dataran medium Jatinangor. Agric. Sci. J 2 (1), 31-52.

Budiarti, S.G. 2005. Karakterisasi beberapa sifat kuantitatif plasma nuftah gandum (Triticum aesticum L.). Buletin Plasma Nuftah 11(2): 49 - 54.

Ferris R., R.H. Ellis, T.R. Wheeler, and P. Hadley. 1999. Effect of high temperature stress at anthesis on grain yield and biomass of field grown crops of wheat. Plant Cell Environ. 34:67-78.

Guendoz, A. and K. Maamari. 2012. Grainfilling, chlorophyll content in relation with grain yield component of durum wheat in a mediterranean environment. Afr. Crop Sci. J, 20(1): $31-37$ 
Ma, J.F. 2003. Role of silicon in enhancing the resistance of plants to biotic and abiotic stresses. Soil Sci. Plant Nutr., 50 (1): 11 - 18.

Makarim, A.K., E. Suhartatik, dan A. Kartohardjono. 2007. Silikon: hara penting pada tanaman padi. Iptek Tanaman Pangan 2(2): 195 - 204.

Nur, Amin. 2013. Adaptasi Tanaman Gandum (Triticum aestivum L.) Toleran Suhu Tinggi dan Peningkatan Keragaman Genetik Melalui Induksi Mutasi dengan Menggunakan Iradiasi Sinar Gamma. Sekolah Pasca Sarjana, Institut Pertanian Bogor.

Nurmala, T., A.W. Irwan, A. Wahyudin, dan F.Y. Wicaksono. 2015. Agronomi Tropis. Penerbit Giratuna. Bandung.

Samosir, A.P., 2011. Adaptabilitas varietas gandum introduksi di bogor. IPBogor. Skripsi.

Saradadevi, R., H. Bramley, K.H.M. Siddique, E. Edwards, and J.A. Palta. 2014. Contrasting stomatal regulation and leaf $A B A$ concentrations in wheat genotypes when split root systems were exposed to terminal drought. Field Crop Research 162: 77 - 86.

Sari, A.T., S.W.A. Suedy, S. Haryanti. 2017. Pengaruh pupuk nanosilika terhadap pertumbuhan dan produksi tanaman kapas (Gossypium hirsutum L. Var. Kanesia 8). J. Biologi, 6(2): 75 - 83
Song, A., P. Li, Z. Li, F. Fan, M. Nikolic, and Y. Liang. 2011. The alleviation of zinc toxicity by silicon is related to zinc transport and antioxidative reactions in rice. Plant Soil, 344: 319 - 333.

Sujatha, K.B., S.M. Babu, S. Ranganathan, D.N. Rao, S. Ravichandran, dan S.R. Voleti. 2013. Silicon accumulation and its influence on some of the leaf characteristics, membrane stability and yield in rice hybrids and varieties grown under aerobic conditions. J. of Plant Nutr., 36: 963 - 975

Taiz, L., and E. Zeiger. 2002. Plant Physiology, 3rd Ed. Sinauer Associates. Sunderland.

Vasanthi, N., L.M. Saleena, and S.A. Raj. 2014. Silicon in crop production and crop protection - A review. Agri. Reviews, 35 (1): $14-23$

Wahyu, Y., A..P Samosir, dan S.G. Budiarti. 2013. Adaptabilitas genotipa gandum introduksi di dataran rendah. Bul. Agrohorti 1(1): 1-6.

Wicaksono, F., Y. Maxiselly., O. Mulyani., dan M.I. Janitra. 2016. Pertumbuhan dan hasil gandum (Triticum aestivum L.) yang diberi perlakuan pupuk silikon dengan dosis yang berbeda di dataran medium Jatinangor. Universitas Padjadjaran. Jurnal Kultivasi 15(3): 179 - 186. 